\title{
Professor T W Wikramanayake
}

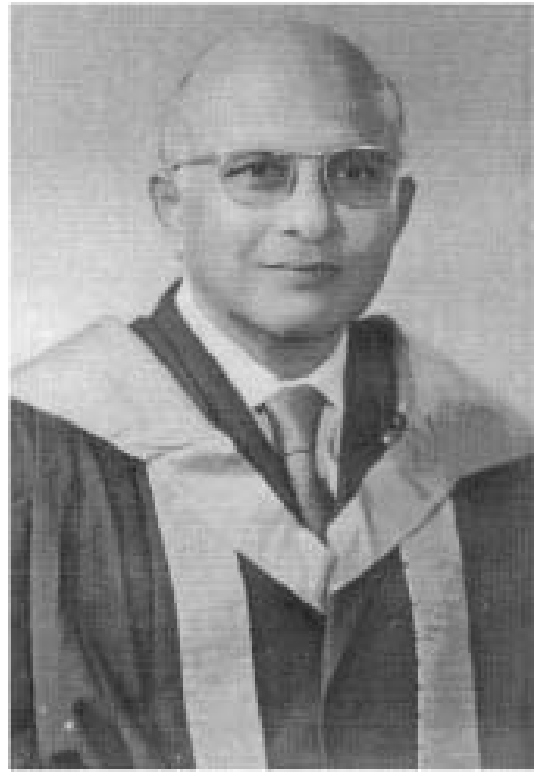

Professor Thomas (Tommy) Walter Wikramanayake was born on 9 April 1918 and hailed from Baddegama, a village in the south of Sri Lanka. He received his school education at St. Thomas' College, Mt. Lavinia and obtained the MBBS degree from the Colombo Medical College. After serving as a medical officer at Matara Hospital, he joined the Faculty of Medicine, Colombo in 1947 as a lecturer in Physiology. He was awarded the $\mathrm{PhD}$ from the University of Glasgow, Scotland in 1952. He served as a Senior Lecturer and Head, sub-department of Biochemistry, Faculty of Medicine, University of Ceylon, Peradeniya. He was later appointed the founder Professor of Biochemistry and Head of Department of Biochemistry at the University of Peradeniya and held this post from 1972 to 1980 .

While serving as Lecturer, he met Eugene Jayasekera who was a medical student at that time. They were married in 1959 and Mrs. Wikramanayake also joined the Faculty of Medicine, University of Peradeniya, and later became Professor of Anatomy. They have three sons, who have excelled in their chosen fields. He adored his five grandchildren and has dedicated his last book to them.

My association with Professor Wikramanyake dates back to 25 years, as our work and research interests were similar. His research in nutritional Biochemistry focused on common nutritional problems in Sri Lanka. He has published extensively and has publications in many prestigious local and international journals, including the Biochemical Journal, British Medical Journal, Journal of Applied Physiology, British Journal of Nutrition, Ceylon Medical Journal and the Ceylon Journal of Medical Science. As the editor of the Ceylon Journal of Medical Science, he compiled the bibliography of research on nutrition in Sri Lanka.
He pioneered the development of Nuclear Medicine in Sri Lanka and was the first Director of the Nuclear Medicine Unit at the University of Peradeniya. In 1980 he moved to Galle where he was actively involved in setting up the Ruhuna Medical Faculty at Karapitiya. He served as the founder Dean and Professor of Biochemistry of the Faculty of Medicine at the University of Ruhuna until his retirement in 1984. He also served as Assistant Director and Visiting Professor of Biochemistry at the North Colombo Medical College, Ragama.

Professor Wikramanyake was elected Emeritus Professor of Biochemistry at the University of Peradeniya in 1985 and was later conferred the Degree of Doctor of Science (Honoris causa) by the same university and by the University of Ruhuna in 1987. In recognition of his outstanding contribution in the field of Nutrition, the University of Glasgow also honoured him by conferring the Degree of Doctor of Science (Honoris causa). He was elected a Fellow of the National Academy of Sciences of Sri Lanka in 1994.

He has been a Rockefeller Research Fellow at the University of Wisconsin and University of California, Berkeley and at the Institute of Nutrition for Central America and Panama (INCAP) in Guatemala City, Guatemala. He has also served as a Senior Tropical Medicine Research Fellow at the London School of Hygiene and Tropical Medicine, Visiting Professor at the University of Leningrad, USSR and at the University of West Indies.

Professor Wikramanayake was not only an academic, but also a sportsman. He was the first captain of swimming in the University College, Colombo. He has also produced and directed six plays for the University Drama Society in Colombo. He took an active interest in student welfare and served as the sub-warden and warden of several halls of residence at the University of Peradeniya. He was a prolific writer and has published several books on nutrition, including Foods and Diets, Food and Nutrition, and the latest being Nutrition Throughout the Life Cycle, which are popular textbooks used by medical and other students in the field of nutrition. He was also instrumental in organising the MSc course in Food and Nutrition at the University of Kelaniya. He was a member of the team that conducted the island-wide survey on physical fitness and dietary habits.

His expert opinion in nutrition was sought after for nearly 50 years. He served as Honorary Consultant to the Nutrition Unit, Ministry of Plan Implementation from 1977. He was a member of the Sri Lankan team to the first International Study Symposium on "Policy making and planning to reduce malnutrition" at the University of California, Berkeley, USA in 1977. He has also been a member of the team of consultants appointed by the Ministry of Plan Implementation for the "Integrated rural 
development programme". He served as a member of the national panel on nutrition education appointed by the Ministry of Plan Implementation. He contributed to and assisted in drafting the Sri Lanka country report to the international conference on Nutrition in Rome in 1991. He also drafted the national nutrition plan of action for the FAO on 1993. He coordinated the efficacy trial on "Iron fortification of wheat flour" and a study on "Control of iron deficiency" for the Ministry of Plan Implementation during the period 1997 to 1998.

He was a founder member of the Nutrition Society of Sri Lanka and as its secretary, drafted a memorandum on the need for a National Nutrition Council under the then Prime Minister, to integrate activities related to Food and Nutrition in all ministries. This resulted in the creation of a Food and Nutrition Policy Planning Division and the setting up of a National Nutrition Committee. As President of the Nutrition Society of Sri Lanka he presided over the first scientific sessions of the society on the theme "Nutrition and National Development". The Nutrition Society continued to draw upon his knowledge and experience on many issues. In recognition of his service to the country, Professor Wikramanayake was felicitated by the Nutrition Society of Sri Lanka in 1999 and by the Sri Lanka Association for the Advancement of Science (Section A) jointly with the Physiological Society of Sri Lanka in 2008.

He was a kind, but forthright person, who always spoke up for Sri Lanka at many local and international meetings. His immense contribution towards improving the nutrition and well being of the people of our country will be remembered forever.

\section{Sunethra Atukorala}

President, National Academy of Sciences of Sri Lanka and Senior Professor of Biochemistry, Faculty of Medicine, University of Colombo, Sri Lanka.

E-mail: <sunethra@eol.lk> 